\title{
Carcass characteristics and serum metabolites of finishing broiler chickens fed $8 \%$ crude fibre diets at three energy lev- els with or without enzyme
}

\author{
*R. I. SALAMI \& A. A. ODUNSI \\ (R. I. S.: Department of Agricultural Education, Animal Science Division, School of Vocational \\ \& Technical Education, Emmanuel Alayande College of Education, P.M.B 1010, Oyo, Oyo State, \\ Nigeria; A. A. O. : Department of Animal Nutrition and Biotechnology, Faculty of Agricultural \\ Sciences, Ladoke Akintola University of Technology, P.M.B 4000, Ogbomoso, Oyo State, Nigeria) \\ "Corresponding author's email: risalami4@gmail.com or risalami@eacoed.edu.ng
}

\begin{abstract}
This study evaluated the carcass characteristics and serum metabolites of broiler finishers fed $8 \% \mathrm{CF}$ diets with or without Roxazyme ${ }^{\circledR} \mathrm{G}^{2} \mathrm{G}$ inclusion at three energy levels maintained at constant, calorie: protein ratio, for 56 days. One hundred and forty-four unsexed Obamarshal day-old broiler chickens were allotted to six dietary treatments at 24 birds per treatment of three replicates. The six treatments diet were produced from three basal diets for each phase at caloric concentrations of 2600, 2800 and $3000 \mathrm{ME}(\mathrm{kcal} / \mathrm{kg})$ to which 0 and $200 \mathrm{mg}$ of Roxazyme ${ }^{\circledR} \mathrm{G}^{2} \mathrm{G}$ were added per $\mathrm{kg}$ diet. Each replicate group was provided feed and water ad libitum in the deep litter and battery cage cells during the starter and finisher phases each of 28-day period respectively. Carcass parameters, gut length, organ weights and serum metabolites were measured according to established standard methods. Data were subjected to one-way analysis of variance in accordance with $2 \times 3$ factorial arrangement and means separated by Duncan Multiple Range Test (DMRT) at $\mathrm{P}<0.05$. Results showed that carcass yield of the birds fed $8 \% \mathrm{CF}$ diet at $2600 \mathrm{ME}(\mathrm{kcal} / \mathrm{kg}$ ) diet with enzyme was comparable to those on 2800 and $3000 \mathrm{ME}(\mathrm{kcal} / \mathrm{kg})$ diets with or without enzyme. Gizzard fat, abdominal fat, serum glucose and cholesterol were also minimized in birds fed $2600 \mathrm{ME}$ diet in addition to enzyme. Serum total protein, albumin, urea and creatinine were not significantly $(\mathrm{P}>0.05)$ affected by treatment diets. It was therefore, concluded that higher dietary ME levels with or without enzyme increased carcass fat, blood glucose and cholesterol levels which must be considered in broiler chicken production for the health benefit of broiler consumers. Thus, it is recommended to produce broiler chickens on $8 \% \mathrm{CF}$ diet at $2600 \mathrm{ME}(\mathrm{kcal} / \mathrm{kg})$ diet with the supplemental Roxazyme ${ }^{\circledR} \mathrm{G}^{2} \mathrm{G}$ in order to reduce carcass fat, blood cholesterol and glucose without compromising carcass yield.
\end{abstract}

Original scientific paper: Received 7 Apr 18; revised 20 Nov18

\section{Introduction}

Traditionally broiler chicken is commonly raised in the tropics on dietary Metabolisable Energy (ME) and Crude Fibre (CF) levels ranging from 2800 to $3000 \mathrm{ME}(\mathrm{kcal} / \mathrm{kg})$ and 3 to $5 \%$ CF respectively (Aduku, 2004; NRC,
1994). Owing to its genetic potential, broiler chicken raised on high- energy diet has propensity to deposit fat because of the tendency to over consume such diet. (Tion et al., 2005; Udedibie et al., 2015).

Ghana Jnl Agric. Sci. 53, 73 - 83

GJAS is an Open Access Journal and distributed under the terms of the Creative Commons (CC) License [CC BY 4.0] 
For healthy living, consumers' preference is currently shifting to low-cholesterol or lowfat animal products such as table meat and egg (Shang et al., 2010; Udedibie et al., 2015). This consumers' preference therefore calls for adoption of management strategies by the broiler farmers to produce lean or fat-free table meat to avoid health risks associated with the consumption of animal fat. Meanwhile, quantitative and qualitative feed restriction procedures have been carefully employed to utilize the feature of compensatory growth in the broiler chicken in order to reduce carcass fat (abdominal fat) and feed cost without adverse effects on performance (Oyedeji et al., 2003; Udedibie et al., 2015). For the same reasons, the use of low energy-low protein (LELP) diet has also been recommended (Dairo et al., 2010). Earlier reports indicated that the lower the dietary $\mathrm{ME}$ level, the lower the broiler carcass fat. Likewise, the higher the dietary CF level, the lower the broiler carcass fat and vice versa (Salami \& Odunsi, 2017b). However, $2600 \mathrm{ME}$ (kcal/kg) diet at three CF levels without enzyme did not support optimum biologic performance in the broiler chicken (Salami \& Odunsi, 2017c,d). In another study by Salami \& Odunsi (2018b), it was shown that Roxazyme ${ }^{\circledR} \mathrm{G}^{2} \mathrm{G}$-treated 2600 $\mathrm{ME}(\mathrm{kcal} / \mathrm{kg})$ diet at $8 \% \mathrm{CF}$ level sustained optimum growth performance which was comparable to those raised on optimal ME levels at the same CF level with or without enzyme. However, the effect of Roxazyme ${ }^{\circledR} \mathrm{G}^{2} \mathrm{G}$ supplementation of $8 \% \mathrm{CF}$ diet at the three $\mathrm{ME}$ levels on carcass characteristics and serum metabolites of broiler finishers has not been reported.

Based on the previous report (Salami \& Odunsi, 2017a), haematological indices in the finishing broiler chickens were not significantly affected by the varying levels of $\mathrm{CF}$ and $\mathrm{ME}$ and likewise their interaction. Similarly, serum metabolites except cholesterol and glucose in the broiler finishers were also not affected by the variable factors of $\mathrm{CF}, \mathrm{ME}$ and likewise their interaction (Salami \& Odunsi, 2017a). The varying levels of $\mathrm{CF}$, enzyme and their interaction in sub-optimum energy diets did not adversely affect serum metabolites except cholesterol and glucose in the broiler finishers (Salami \& Odunsi, 2017e).

This study, therefore, is aimed at evaluating the carcass characteristics and serum metabolites of finishing broiler chickens raised on 8\% CF diets at three ME levels with or without supplemental Roxazyme ${ }^{R} \mathrm{G}^{2} \mathrm{G}$. The intent is to produce wholesome broiler carcass to meet consumers' choice.

\section{Materials and methods}

Experimental site

The study was conducted at the Poultry unit of the Teaching and Research farm, Emmanuel Alayande College of Education, Oyo, Nigeria. Oyo is $850 \mathrm{~m}$ above the sea level and is located approximately along latitude $7^{0} 51^{1}$ North of the equator and longitude $3^{0} 57^{1}$ East of the Greenwich meridian. The annual mean rainfall, temperature and relative humidity in Oyo are $1163 \mathrm{~mm}, 27^{\circ} \mathrm{C}$ and $82 \%$ respectively (Iwena, 2012).

\section{Experimental diets}

Three 8\% CF basal diets each for the starter and finisher phases (Table 1) were formulated to contain 2600, 2800 and $3000 \mathrm{ME}(\mathrm{kcal} / \mathrm{kg})$. From these basal diets were produced six treatment diets labeled A, B, C, D, E and F in 2 by 3 factorial arrangement in ascending order of $\mathrm{ME}$ level with or without enzyme supplementation. Diets B, D and F were supplemented with 200 mg of Roxazyme ${ }^{\circledR} \mathrm{G}^{2} \mathrm{G} / \mathrm{kg}$ of the diets as per the recommendations of the manufacturer of 
the enzyme (DSM Nutritional Products Limited, Switzerland) while the rest of diets were not supplemented with the enzyme. The entire treatment diets maintained similar calorie: protein ratios (based on calculated percent $\mathrm{CP}$ and $\mathrm{ME}$ values) in accordance with the recommendation of Olomu (1995) and Aduku (2004) for the broiler starter (123:1) and finisher phases (140:1).

\section{Experimental Protocol}

One hundred and forty-four day-old unsexed Obamarshal broiler chicken were divided into six treatment groups of 24 birds per treatment and three replicates (of 8 birds each) per treatment. Treatment diets were allocated in Completely Randomised Design (CRD) to the replicate groups. During the starter phase from day-old to 4 weeks of age, the birds per replicate were housed and brooded in the deep litter pen partitioned into units or cells, each of them measuring $45 \times 75 \mathrm{~cm}$ for breadth and length respectively as described by Salami \& Odunsi (2017d). Dried fine water erosion sand was used as the litter material and at a depth of 4 to $5 \mathrm{~cm}$ instead of wood shavings to prevent the birds from picking fibre from wood shavings (Esmail, 2012). Each cell was equipped with a 100 watts electric bulb to provide light and heat for the birds. In the event of electric power failure, burning charcoal pots were used and positioned in the brooder pen to provide adequate heat for the birds.

At 5 weeks of age, birds on the respective treatment diets in the starter phase were transfered into two tier battery cage with 2 birds per cage compartment cell measuring $30 \times 38$ x 43 $\mathrm{cm}^{3}$ for length, breadth and height respectively (Salami \& Odunsi, 2017c). The birds were vaccinated against Newcastle, Gumboro and fowl pox diseases and also protected from bacterial and coccidial infections accordingly (Salami, 2009). The study was conducted in the dry season of the year 2013. 
TABLE 1

Formulation and chemical composition of $8 \%$ Crude Fibre Basal Diets

\begin{tabular}{|c|c|c|c|c|c|c|}
\hline \multirow[b]{3}{*}{ Feed ingredients } & \multicolumn{3}{|c|}{ Starter Diets } & \multicolumn{3}{|c|}{ Finisher Diets } \\
\hline & 2600 & 2800 & 3000 & 2600 & 2800 & $3000 M E$ \\
\hline & & & & & & (Kcal/Kg diet) \\
\hline Maize & 33 & 32 & 24 & 39 & 38 & 30 \\
\hline Rice Offal & 12 & 11 & 11 & 12 & 10 & 10 \\
\hline Palm Kernel Cake & 2 & 10 & 10 & 2 & 10 & 10 \\
\hline Wheat Offal & 18 & 10 & 10 & 19 & 12 & 12 \\
\hline Groundnut Cake & 17 & 15 & 15 & 15 & 12 & 12 \\
\hline Blood meal & 6 & 8 & 10 & 4 & 6 & 8 \\
\hline Danish Fish meal & 3 & 4 & 5 & 2 & 3 & 4 \\
\hline Palm oil & 3 & 5 & 10 & 2 & 4 & 9 \\
\hline Sterilised sand & 1 & - & - & - & - & - \\
\hline aFixed ingredients & 5 & 5 & 5 & 5 & 5 & 5 \\
\hline Total & 100 & 100 & 100 & 100 & 100 & 100 \\
\hline \multicolumn{7}{|l|}{ Calculated Chemical } \\
\hline $\begin{array}{l}\text { Metabolisable energy } \\
\text { (Kcal/kg) }\end{array}$ & 2628.3 & 2820.3 & 3029.1 & 2621.9 & 2806.9 & 3015.0 \\
\hline Lysine $(\%)$ & 1.10 & 1.20 & 1.31 & 0.90 & 1.00 & 1.06 \\
\hline Methionine (\%) & 0.30 & 0.48 & 0.54 & 0.31 & 0.39 & 0.45 \\
\hline Calorie : Crude Protein & 123.2 & 123.3 & 124.1 & 140.0 & 139.6 & 139.3 \\
\hline \multicolumn{7}{|l|}{${ }^{c}$ DeterminedChemical } \\
\hline \multicolumn{7}{|l|}{ Fractions (\%) } \\
\hline Crude fat (\%) & 7.17 & 10.23 & 12.57 & 4.63 & 7.51 & 11.62 \\
\hline Dry matter & 89.77 & 89.64 & 89.26 & 90.03 & 90.26 & 88.27 \\
\hline Crude Protein (\%) & 20.45 & 21.72 & 23.50 & 17.59 & 19.30 & 20.65 \\
\hline Crude fibre (\%) & 7.80 & 7.88 & 7.75 & 7.75 & 7.68 & 7.60 \\
\hline Phosphorus (\%) & 0.69 & 0.77 & 0.76 & 0.68 & 0.70 & 0.69 \\
\hline Calcium (\%) & 2.15 & 2.20 & 2.25 & 1.88 & 1.93 & 1.85 \\
\hline
\end{tabular}

${ }^{a}$ Made up of $2.5 \%$ bone meal, $2 \%$ oyster shell, $0.25 \%$ salt, and $0.25 \%$ broiler premix

${ }^{\mathrm{c}}$ Means of triplicate determinations.

\section{Data collection}

Blood samples were drawn from 3 birds per treatment diet (i.e one bird per replicate) at 50 days of age. The blood ( $3 \mathrm{mls}$ ) was collected asceptically from the neck veins of the sampled birds into non-heparinised sample bottles. The blood samples were immediately centrifuged to separate and decant serum for deep freezing until needed for serum analyses. Serum analyses were subsequently carried out in triplicate to measure total protein, albumin, urea, creatinine, glucose and cholesterol using the estab- lished standard procedures outlined in Salami \& Odunsi (2017e).

Four sampled birds (comprising two males and two females per treatment and each serving as a replicate) whose pre-slaughter weights were close to the treatment mean were sacrificed at 56 days of age. Carcass and organ evaluation were carried out according to the procedures described by Salami \& Odunsi (2017b). The carcass parameters measured included pre-slaughter, post slaughter, plucked and eviscerated weights. Length of the gut sec- 
tions determined were those of the small and large intestines, paired caeca and colorectum. Weight of the visceral and digestive organs were also measured and expressed in relation to the pre-slaughter weight of the slaughtered birds.

\section{Chemical analysis}

Basal diets for the starter and finisher phases were analysed according to AOAC (2000) for dry matter, crude protein, crude fibre, crude fat, calcium and phosphorus.

\section{Statistical Analysis}

Data were subjected to one-way analysis of variance (ANOVA) in accordance with $2 \times 3$ factorial arrangement comprising 2 levels of Roxazyme ${ }^{\circledR} \mathrm{G}^{2} \mathrm{G}$ inclusion $(0$ and $200 \mathrm{mg} / \mathrm{kg}$ diet/energy level and 3 levels of ME (2600,
2800 and $3000 \mathrm{ME}(\mathrm{kcal} / \mathrm{kg}$ ) using SAS (2000) statistical package. Means were separated using Duncan's Multiple Range Test of the same package at $5 \%$ probability level.

\section{Results}

Superior $(\mathrm{P}<0.05)$ pre- and post- slaughter weights as well as plucked and eviscerated weights were attained by birds fed 2800 and $3000 \mathrm{ME}(\mathrm{kcal} / \mathrm{kg})$ diets in comparison with the values recorded for birds on $2600 \mathrm{ME}$ $(\mathrm{kcal} / \mathrm{kg}$ ) diet (Table 2). However, there was no consistent effect of dietary energy levels on gut length of the sacrificed birds. Inclusion of Roxazyme ${ }^{\circledR} G^{2} G$ in the broiler finisher diets did not significantly affect the pre-and post-slaughter, plucked and eviscerated weights as well as the gut length of the birds (data not presented).

TABLE 2

Effect of varying levels of dietary energy of $8 \%$ crude fibre diets on carcass parameters and gut length of broiler finishers at 56 days of age

\begin{tabular}{lllll}
\hline Carcass parameters: & 2600 & 2800 & 3000 & \pm SEM \\
\hline Pre-slaughter weight at 56 days $(\mathrm{kg} / \mathrm{b})$ & $2.14^{\mathrm{b}}$ & $2.39^{\mathrm{a}}$ & $2.31^{\mathrm{a}}$ & 0.05 \\
Post-slaughter weight $(\mathrm{kg} / \mathrm{b})$ & $2.02^{\mathrm{b}}$ & $2.27^{\mathrm{a}}$ & $2.18^{\mathrm{a}}$ & 0.05 \\
Plucked weight $(\mathrm{kg} / \mathrm{b})$ & $1.95^{\mathrm{b}}$ & $2.17^{\mathrm{a}}$ & $2.13^{\mathrm{ab}}$ & 0.03 \\
Eviscerated weight $(\mathrm{kg} / \mathrm{b})$ & $1.48^{\mathrm{b}}$ & $1.59^{\mathrm{a}}$ & $1.60^{\mathrm{a}}$ & 0.03 \\
Gut length $(\mathrm{cm} / \mathrm{kg})$ : & & & & \\
Small intestine & $82.77^{\mathrm{a}}$ & $76.34^{\mathrm{b}}$ & $84.09^{\mathrm{a}}$ & 0.79 \\
Large intestine & $22.42^{\mathrm{a}}$ & $19.22^{\mathrm{b}}$ & $20.57^{\mathrm{ab}}$ & 1.88 \\
Combined caeca & $17.17^{\mathrm{a}}$ & $15.31^{\mathrm{b}}$ & $16.72^{\mathrm{ab}}$ & 0.61 \\
Colo-rectum & 5.08 & 4.41 & 4.47 & 0.20 \\
\hline
\end{tabular}

a,b, Means within the same row bearing identical or no superscript are similar $(\mathrm{P}>0.05)$ while those with unidentical superscripts differ. $(\mathrm{P}<0.05)$.

However, interaction effect showed that the pre - and post - slaughter weights as well as the plucked and eviscerated weights of the birds fed Roxazyme ${ }^{\circledR} \mathrm{G}^{2} \mathrm{G}$ supplemented 2600 $\mathrm{ME}(\mathrm{kcal} / \mathrm{kg})$ diet were better $(\mathrm{P}<0.05)$ than those fed with unsupplemented $2600 \mathrm{ME}$ (kcal/ $\mathrm{kg}$ ) diet. The carcass parameters of the birds on the enzyme-supplemented $2600 \mathrm{ME}(\mathrm{kcal} / \mathrm{kg})$ diet were comparable with those on the other energy levels with or without enzyme inclusion (Table 3). Interaction effects of enzyme and energy levels (Table 3 ) on the gut length was also inconsistent as observed in the main effect of energy level. 
TABLE 3

Interaction effects of varying levels of dietary energy and enzyme supplementation of $8 \%$ crude fibre diets on carcass parameters and gut length of broiler finishers at 56 days of age.

\begin{tabular}{|c|c|c|c|c|c|c|c|}
\hline \multicolumn{3}{|c|}{2600} & \multicolumn{2}{|c|}{2800} & \multicolumn{2}{|c|}{$3000 \mathrm{ME}(\mathrm{kcal} / \mathrm{kg}) \mathrm{die}$} & \multirow[b]{2}{*}{ $\pm S E M$} \\
\hline Carcass parameters & A & $B+e$ & C & $D+e$ & $E$ & $F+e$ & \\
\hline $\begin{array}{l}\text { Pre-slaughter weight at } 56 \text { days } \\
(\mathrm{kg} / \mathrm{b})\end{array}$ & $2.04^{\mathrm{c}}$ & $2.24^{\mathrm{b}}$ & $2.45^{\mathrm{a}}$ & $2.33^{\mathrm{a}}$ & $2.31^{\mathrm{ab}}$ & $2.30^{\mathrm{ab}}$ & 0.06 \\
\hline Post-slaughter weight (kg/b) & $1.93^{\mathrm{c}}$ & $2.11^{\mathrm{b}}$ & $2.31^{\mathrm{a}}$ & $2.24^{\mathrm{a}}$ & $2.21^{\mathrm{ab}}$ & $2.15^{\mathrm{ab}}$ & 0.06 \\
\hline $\begin{array}{l}\text { Plucked weight }(\mathrm{kg} / \mathrm{b}) \\
\text { Eviscerated weight }(\mathrm{kg} / \mathrm{b})\end{array}$ & $1.88^{\mathrm{c}}$ & $2.03^{\mathrm{b}}$ & $2.18^{\mathrm{a}}$ & $2.17^{\mathrm{a}}$ & $2.15^{\mathrm{a}}$ & $2.11^{\mathrm{ab}}$ & 0.05 \\
\hline Gut length $(\mathrm{cm} / \mathrm{kg})$ : & $1.39^{\mathrm{c}}$ & $1.58^{\mathrm{b}}$ & $1.76^{\mathrm{a}}$ & $1.63^{\mathrm{a}}$ & $1.64^{\mathrm{a}}$ & $1.56^{\mathrm{b}}$ & 0.05 \\
\hline Small intestine & $84.78^{\mathrm{ab}}$ & $80.75^{\mathrm{bc}}$ & $72.57^{\mathrm{c}}$ & $80.11^{\text {bc }}$ & $80.48^{\mathrm{bc}}$ & $87.69^{\mathrm{a}}$ & 2.53 \\
\hline Large intestine & $23.38^{\mathrm{a}}$ & $21.45^{\mathrm{ab}}$ & $19.08^{\mathrm{b}}$ & $19.36^{\mathrm{b}}$ & $20.35^{\mathrm{b}}$ & $20.78^{b}$ & 1.05 \\
\hline Combined caeca & $17.45^{\mathrm{a}}$ & $16.89^{\mathrm{ab}}$ & $15.23^{\mathrm{b}}$ & $15.38^{\mathrm{b}}$ & $16.03^{\mathrm{ab}}$ & $17.40^{\mathrm{a}}$ & 0.81 \\
\hline Colo-rectum & $5.29^{\mathrm{a}}$ & $4.87^{\mathrm{ab}}$ & $4.13^{\mathrm{b}}$ & $4.68^{\mathrm{ab}}$ & $4.12^{\mathrm{b}}$ & $4.81^{\mathrm{ab}}$ & 0.27 \\
\hline
\end{tabular}

$\overline{\mathrm{a}, \mathrm{b}, \mathrm{c}}$ Means within the same row bearing identical or no superscript are similar $(\mathrm{P}>0.05)$ while those with unidentical superscripts differ significantly $(\mathrm{P}<0.05)$.

$+\mathrm{e}=$ supplementation with $200 \mathrm{mg}$ Roxazyme ${ }^{\circledR} \mathrm{G}^{2} \mathrm{G}$ per $\mathrm{kg}$ diet.

The weight of the visceral organs except gizzard, paired caeca and small intestine) were the heart and giblet as well as the colorectum of not affected by dietary energy levels. The abthe sacrificed chickens (Table 4) were not sig- dominal fat was smaller $(\mathrm{P}<0.05)$ in the birds nificantly affected $(\mathrm{P}>0.05)$ by the dietary en- fed $2600 \mathrm{ME}(\mathrm{kcal} / \mathrm{kg})$ diet as compared with ergy levels. However, the weight of the diges- those fed 2800 and $3000 \mathrm{ME}(\mathrm{kcal} / \mathrm{kg})$ diets. tive organs (such as the crop, proventriculus,

TABLE 4

Effect of varying levels of dietary energy of $8 \%$ crude fibre diets on organ weights of broiler finishers at 56 days of age.

\begin{tabular}{lllll}
\hline & \multicolumn{3}{l}{ Dietary energy levels (Kcal.ME/Kg diet) } & \\
\cline { 2 - 4 } Organ (\% of live weight) & 2600 & 2800 & 3000 & \pm SEM \\
\hline Trachea & 0.21 & 0.18 & 0.20 & 0.01 \\
Heart & $0.49^{\mathrm{b}}$ & $0.49^{\mathrm{b}}$ & $0.97^{\mathrm{a}}$ & 0.02 \\
Lung & 0.47 & 0.45 & 0.49 & 0.01 \\
Spleen & 0.17 & 0.13 & 0.16 & 0.01 \\
Giblet (Liver and Bile) & $0.97^{\mathrm{b}}$ & $1.69^{\mathrm{a}}$ & $1.72^{\mathrm{a}}$ & 0.04 \\
Crop & 0.44 & 0.46 & 0.41 & 0.02 \\
Proventriculus & 0.47 & 0.43 & 0.42 & 0.02 \\
Intact gizzard & 2.57 & 2.64 & 2.62 & 0.05 \\
Cleaned gizzard & 1.77 & 1.56 & 1.84 & 0.04 \\
Gizzard fat & 0.51 & 0.50 & 0.49 & 0.04 \\
Abdominal fat & $1.16^{\mathrm{b}}$ & $1.67^{\mathrm{a}}$ & $1.67^{\mathrm{a}}$ & 0.09 \\
Colo-rectum & $0.40^{\mathrm{a}}$ & $0.16^{\mathrm{b}}$ & $0.17^{\mathrm{b}}$ & 0.01 \\
Combined caeca & 0.63 & 0.51 & 0.53 & 0.02 \\
Small intestine & 3.35 & 3.74 & 3.41 & 0.07 \\
Large intestine & $0.81^{\mathrm{a}}$ & $0.77^{\mathrm{a}}$ & $0.69^{\mathrm{b}}$ & 0.02 \\
\hline
\end{tabular}


${ }^{\mathrm{a}, \mathrm{b}}$ Means within the same row bearing identical or no superscript are similar $(\mathrm{P}>0.05)$ while those with unidentical superscripts differ significantly $(\mathrm{P}<0.05)$.

The weight of other organs except gizzard fat and abdominal fat was not affected $(\mathrm{P}>0.05)$ by enzyme inclusion (data not presented). In line with the main effect of energy and enzyme inclusion level, there was generally no interaction effect on the visceral organs, including gizzard (Table 5). However, the weight of gizzard fat and abdominal fat tended to increase with increase in dietary energy level and reduce with enzyme inclusion in the experimental diet.

TABLE 5

Interaction effects of varying levels of dietary energy and enzyme supplementation of $8 \%$ crude fibre dietson organ weights of broiler finishers at 56 days of age.

\begin{tabular}{|c|c|c|c|c|c|c|c|}
\hline \multirow{2}{*}{$\begin{array}{l}\text { Organ ( } \% \text { of live } \\
\text { weight) }\end{array}$} & \multicolumn{2}{|c|}{2600} & \multicolumn{2}{|c|}{2800} & \multicolumn{2}{|c|}{$3000 \mathrm{ME}(\mathrm{kcal} / \mathrm{kg}) \mathrm{diet}$} & \multirow[b]{2}{*}{ \pm SEM } \\
\hline & $\mathrm{A}$ & $\bar{B}+\mathrm{e}$ & $\overline{\mathrm{C}}$ & $\overline{\mathrm{D}}+\mathrm{e}$ & $\mathrm{E}$ & $\mathrm{F}+\mathrm{e}$ & \\
\hline Trachea & 0.22 & 0.19 & 0.16 & 0.20 & 0.19 & 0.20 & 0.02 \\
\hline Heart & 0.49 & 0.48 & 0.47 & 0.50 & 0.51 & 0.46 & 0.03 \\
\hline Lung & 0.46 & 0.48 & 0.45 & 0.44 & 0.46 & 0.52 & 0.02 \\
\hline Spleen & 0.13 & 0.20 & 0.12 & 0.14 & 0.18 & 0.14 & 0.01 \\
\hline Giblet (Liver and Bile) & $2.01^{\mathrm{a}}$ & $1.92^{\mathrm{a}}$ & $1.58^{\mathrm{b}}$ & $1.81^{\mathrm{a}}$ & $1.78^{\mathrm{a}}$ & $1.66^{\mathrm{b}}$ & 0.06 \\
\hline Crop & 0.40 & 0.47 & 0.45 & 0.47 & 0.40 & 0.41 & 0.04 \\
\hline Proventriculus & $0.51^{\mathrm{a}}$ & $0.42^{\mathrm{b}}$ & $0.40^{\mathrm{b}}$ & $0.45^{\mathrm{ab}}$ & $0.40^{\mathrm{b}}$ & $0.44^{\mathrm{ab}}$ & 0.02 \\
\hline Intact gizzard & 2.71 & 2.43 & 2.67 & 2.60 & 2.52 & 2.72 & 0.09 \\
\hline Cleaned gizzard & 1.81 & 1.72 & 1.61 & 1.50 & 1.70 & 1.98 & 0.08 \\
\hline Gizzard fat & $0.61^{\mathrm{a}}$ & $0.40^{\mathrm{b}}$ & $0.50^{\mathrm{ab}}$ & $0.49^{\mathrm{ab}}$ & $0.42^{\mathrm{ab}}$ & $0.36^{\mathrm{b}}$ & 0.06 \\
\hline Abdominal fat & $0.63^{\mathrm{b}}$ & $0.68^{\mathrm{b}}$ & $0.77^{\mathrm{b}}$ & $0.57^{\mathrm{b}}$ & $0.97^{\mathrm{ab}}$ & $1.37^{\mathrm{a}}$ & 0.15 \\
\hline Colo-rectum & 0.19 & 0.16 & 0.16 & 0.15 & 0.16 & 0.18 & 0.01 \\
\hline Combined caeca & 0.65 & 0.61 & 0.51 & 0.50 & 0.51 & 0.54 & 0.03 \\
\hline Small intestine & 3.39 & 3.30 & 3.32 & 3.42 & 3.43 & 3.38 & 0.12 \\
\hline Large intestine & 0.84 & 0.77 & 0.68 & 0.86 & 0.66 & 0.72 & 0.03 \\
\hline
\end{tabular}

\footnotetext{
a,b Means within the same row bearing identical or no superscript are similar $(\mathrm{P}>0.05)$ while those with unidentical superscripts differ significantly $(\mathrm{P}<0.05)$. $+\mathrm{e}=$ supplementation with $200 \mathrm{mg}$ Roxazyme ${ }^{\circledR} \mathrm{G}^{2} \mathrm{G}$ per $\mathrm{kg}$ diet.
}

Enzyme inclusion level in the diets had no significant effect on the serum metabolites of the birds (data not presented). Similarly, there was no significant effect of dietary energy levels on the serum metabolites measured except serum cholesterol and glucose (Table
6) as confirmed by interaction effect (data not presented). Serum cholesterol level was lower $(\mathrm{P}<0.05)$ in the birds fed 2600 than those on the 2800 and $3000 \mathrm{ME}(\mathrm{kcal} / \mathrm{kg})$ diets. However, serum glucose tended to be uniform across dietary energy levels as confirmed by the inter- 
action effect. This interaction effect indicated that birds fed 2800 and $3000 \mathrm{ME}(\mathrm{kcal} / \mathrm{kg}) \mathrm{di}-$ ets had higher $(\mathrm{P}<0.05)$ serum cholesterol levels than the birds fed $2600 \mathrm{ME}(\mathrm{kcal} / \mathrm{kg})$ diet. Conclusively, the relatively lower $(\mathrm{P}<0.05)$ carcass fat, serum cholesterol and glucose levels were in favour of $2600 \mathrm{ME}(\mathrm{kcal} / \mathrm{kg})$ diet with Roxazyme ${ }^{\circledR} \mathrm{G}^{2} \mathrm{G}$ inclusion for producing lean broiler carcass without compromising optimum carcass yield.

TABLE 6

Effect of varying levels of dietary energy in $8 \%$ crude fibre diets on serum metabolites of broiler finishers at 50 days of age.

Dietary energy levels ME ( $\mathrm{kcal} / \mathrm{kg}$ diet)

\begin{tabular}{lllll}
\hline Metabolites $(\mathrm{mg} / \mathrm{dl})$ & 2600 & 2800 & 3000 & \pm SEM \\
\hline Total protein & 3.38 & 4.02 & 3.12 & 0.40 \\
Albumin & 1.27 & 1.35 & 1.32 & 0.12 \\
Urea & 13.49 & 12.24 & 13.53 & 0.65 \\
Creatinine & 0.53 & 0.53 & 0.54 & 0.08 \\
Glucose & $219.24^{\mathrm{b}}$ & $212.59^{\mathrm{b}}$ & $245.85^{\mathrm{a}}$ & 21.03 \\
Cholesterol & $84.52^{\mathrm{b}}$ & $96.36^{\mathrm{a}}$ & $97.09^{\mathrm{a}}$ & 2.29
\end{tabular}

$\overline{\mathrm{a}, \mathrm{b}}$.Mean values within the same row bearing identical or no superscript are similar $(\mathrm{P}>0.05)$ while those with unidentical superscripts differ significantly $(\mathrm{P}<0.05)$.

\section{Discussion}

The better carcass yield of the birds on the optimal energy diets with or without supplemental Roxazyme ${ }^{\circledR} \mathrm{G}^{2} \mathrm{G}$ in this study accords with the carcass yield of birds on similar diets in the antecedent report (Salami \& Odunsi, 2017b). This result revalidates the adequacy of these energy levels without enzyme inclusion for optimum growth performance in the broiler chickens as previously reported (Salami \& Odunsi, 2017 c, d). Similarly, the superior carcass parameters of the birds on the Roxazyme ${ }^{\circledR} \mathrm{G}^{2} \mathrm{G}$-treated $2600 \mathrm{ME}(\mathrm{kcal} / \mathrm{kg}$ ) diet (diet B) as compared with the untreated one (diet A) also indicates its nutritional adequacy for optimum growth performance and carcass yield (Salami \& Odunsi, 2018a). This further confirms the extra caloric effect of optimum CF level (8\%) with enzyme inclusion via depolymerisation and microbial fermentation of depolymerisation products (Acamovic, 2001; Johnston et al., 2003; Joze- fiak et al., 2004). However, the extra caloric effect of $8 \%$ CF level upon enzyme inclusion at the sub-optimal energy level did not manifest at the optimal energy levels in this study. This confirms the effect of dietary energy level on the beneficial effects of exogenous polysaccharidase enzymes (Acamovic, 2001; Sundu et al., 2006; Salami \& Odunsi, 2018a) and the need for caution in the application of enzymes in poultry diets (Khattak et al., 2007; Altaf-Ur Rahman et al., 2007; Salami \& Odunsi, 2018b). The maximum values of eviscerataed carcass weight of the birds on diets B, C, D, E and F were comparable and ranged from $1.56 \mathrm{~kg}$ (diet F) to $1.76 \mathrm{~kg}(\operatorname{diet} \mathrm{C})$. These values agree with the published data elsewhere (Odunsi et al., 2005; Tion et al., 2005; Isikwenu et al., 2010). As previously observed by Salami \& Odunsi (2017b), the non-consistent effect of the treatment diets on the gut length of the birds in this study was probably due to similar CF content 
and calorie: protein ratio. Majority of the visceral and digestive organs were not affected by the treatment diets and this is in agreement with earlier findings (Salami \& Odunsi, 2017b). However, the bigger size of the fat depots (adipose tissues) notably the abdominal fat, gizzard fat and heart, especially in the birds fed high-energy diets was attributed to fat deposition occasioned by excessive intake of calorie (Bartov et al., 1974; Tion et al., 2005; Salami \& Odunsi, 2017b). Similarly, the bigger size of the giblet (liver + bile) in the birds fed high-energy diets was also probably attributed to increased metabolic activities of the organ in the regulation of stored fat via hepatic synthesis of cholesterol and bile acids and conversion of fat to glucose (Mc Donald et al., 1995; Jozefiak et al., 2004; Olorode et al., 2007).

The values of blood cholesterol and other metabolites except glucose fell within the standard values for normal chickens as reported by Mitruka \& Rawnsley (1977). This finding suggests that the protein metabolism and health status of the birds were not compromised by the treatment diets since the calorie: protein ratio of the diet was kept within the tolerance limit. Mitruka \& Rawnsley (1977) quoted the values ranging from 52 to $148 \mathrm{mg} / \mathrm{dl}$ and 152 to $182 \mathrm{mg} / \mathrm{dl}$ for serum cholesterol and glucose respectively for normal chickens. However, in this study, there was tendency for increased serum cholesterol level as dietary energy level increased from 2600 to $3000 \mathrm{ME}(\mathrm{kcal} / \mathrm{kg}$ ) (Salami \& Odunsi, 2017a). The $8 \%$ dietary CF level in this study might have assisted the birds to reduce their blood cholesterol level (via excretion of bound bile acids with fibre in the excreta) below the standard value (Shang et al., 2010; Esmail, 2012; Salami \& Odunsi, 2017a). However, the serum glucose level exceeded the standard value given by Mitruka \& Rawnsley
(1977) because of the glucose from the metabolic origin (gluconeogenesis) and simpler carbonhydrates of dietary origin (Salami \& Odunsi, 2017a).

The findings in this study, therefore, are in favour of enzyme-treated $2600 \mathrm{ME}$ (kcal/ $\mathrm{kg}$ ) diet (diet B) for producing low-fat broiler carcass to satisfy consumers' choice. This diet is also expected to be cheaper for broiler production in a tropical environment.

\section{Conclusion and Recommendation}

The objective of this study was to evaluate the carcass characteristics and serum metabolites of broiler chickens raised on $8 \% \mathrm{CF}$ diets at three energy levels with or without Roxaz$y m e^{\circledR} G^{2} G$ inclusion. Carcass yield of the birds on the lowest energy level without supplemental enzyme was poorer but it was optimised with enzyme inclusion to compare with those on the higher energy levels with or without enzyme. Incremental levels of energy significantly increased carcass fat and blood cholesterol while addition of enzyme tended to reduce carcass fat and serum cholesterol. Hence, it is advantageous to produce lean broiler carcass on $8 \% \mathrm{CF}$ diet at $2600 \mathrm{ME}(\mathrm{kcal} / \mathrm{kg})$ with supplemental Roxazyme ${ }^{\circledR} \mathrm{G}^{2} \mathrm{G}$. Diet B is hereby recommended to produce low fat or low cholesterol product (meat) in order to satisfy consumers' preference.

\section{REFERENCES}

Acamovic, T. (2001) Commercial application of enzyme technology for poultry production. Wld. Poult.Sci. J 57 (3), 225 - 242.

Aduku, A. O. (2004) Feed ingredient and diet composition tables for the tropics. Davcon computers and Business Bureau, Kaduna, Nigeria.

Altaf-ur-Rahman, Mohsin Ali, Shoaib Sultan \& Nazir Ahmad, (2007) Economic importance of 
exogenous enzymes in broiler rations. Sarhad $J$. Agric 23 (2), 489 - 492.

A.O.A.C (2000). Association of Official Analytical Chemists. Official methods of analysis. 17th Edition Washington, D.C.

Bartov, I., Bornstein, S. \& Lipstein, B. (1974) Effect of calorie to protein ratio on the degree of fatness in broilers fed on practical diets. Brit. Poult. Sci 15, $107-117$.

Choct, M. (2006) Enzymes for the feed industry: past, present and future. Wld Poult. Sci. J 62 (1), 5 15.

Dairo, F. A. S., Adesehinwa, A. O. K., Oluwasola, T. A. \& Oluyemi, J. A. (2010) High and low dietary energy and protein levels for broiler chickens. African Journal of Agricultural Research. 5 (15), $2030-2038$.

Esmail, S. H. (2012) Fibre plays a supporting role in poultry nutrition. World Poultry, 28 (1).http:// www.worldpoultry.net/chickens/nutrition/layers/fibre-plays-a-supporting-role-in-poultry-nutrition-9965.html.

Isikwenu, J. O., Akpodiete, O. J., Omeje, S. I. \& Okagbare, G. O. (2010) The effects of replacing groundnut cake with urea-treated and fermented brewers' dried grains on nutrient digestibility, retention and carcass characteristics of broiler finishers. Nig. J. Anim. Prod 37 (1), 1 - 12.

Iwena, O. A. (2012) Essential Geography for Senior Secondary Schools. 6th ed Lagos, Tonad Publishers Limited.

Johnston, L. J., Noll, S; Renteria, A. \& Shurson, J., (2003) Feeding By-Products High in Concentration of Fibre to Non-ruminants. Paper presented at the Third National Symposium on Alternative Feeds for Livestock and Poultry held in Kansas City, MO. On Nov. 4, 2003.

Jozefiak, D, Rutkowski, A. \& Martin, S. A. (2004) Carbohydrate fermentation in the avian ceca: a review. Animal Feed Science and Technology 113, $1-15$.

Khattak, F. M; Pasha, T. N.; Hayat, Z. \& Mahmud, A. (2006) Enzymes in Poultry nutrition. J. Anim. Pl. Science 16 (1-2), 1 - 7.

Mc Donald, P., Edwards, R. A. \& Greenheigh, J. F. D (1995) Animal nutrition 4th edition, Longman Group Ltd. UK. pp. 521.

Mitruka, B .M. \& Rawnsley, H. M. (1977) Clinical Biochemical and haematological Reference Values in Normal Experimental Animals. Masson Pub. U.S.A. Inc. NY. pp. 88 \& $140-143$.

NRC (1994) Nutrient requirement of poultry. Published by National Academy of Sciences. Washington, D.C.

Odunsi, A. A., Oladunjoye, I. O. \& Emiola, I. A. (2005) Response of finishing broilers fed varyingdietary protein levels in a tropical environment. International Journal of Applied Agricultural and Apicultural Research 1 (1), 66 - 73.

Olomu, J. M. (1995) Monogastric Animal Nutrition: Principles and Practice. A Jachem Publication. Benin. pp. $67-99$.

Olorode, B. R., Adeniran, R. A. \& Abiola, J. O. (2007) Effect of graded levels of Moringaoleifera seed meal on haematological values and organ weight of broiler chicks. Trop. J. Anim. Sci $10(1 \& 2) 63-67$.

Oyedeji, J. O., Atteh, J. O. \& Adedeji, S. A. (2003) Response of broilers to skip a day feeding. Nig. J. Anim. Prod 30 (2), $163-168$.

S. A. S Institute (2000) Statistical Analysis System. User's Guide, Cary, N.C. USA.

Salami, R. I. (2009) Unmilled rice offal as a replacement for maize in the enzyme-supplemented diets of broiler starters: effects on live performance traits. Proceedings of 14th Annual conference of Animal Science Society of Nigeria (ASAN) 
Sept., 14-17. LAUTECH, Ogbomoso, Nigeria. pp. $481-483$

Salami, R. I. \& Odunsi, A. A. (2017a) Blood profile of Broiler chickens fed varying levels of Crude fibre and energy in Multi-Fibre Source-Based Diets for Broiler Chickens. Nig. J. Anim. Prod 44 (2), 86 - 95.

Salami, R. I. \& Odunsi, A. A. (2017b) Carcass characteristics of finishing broiler chickens fed varying levels of crude fibre and energy in multi-fibre source-based diets. Nig. J. Anim. Prod 44 (2),122 -131 .

Salami, R. I. \& Odunsi, A. A. (2017c) Effect of varying dietary fibre and energy levels in multi-fibre source-based diets on growth performance of broiler finisher chickens. Nig. J. Anim. Sci 19 (2), $72-82$.

Salami, R. I. \& Odunsi, A. A. (2017d) Growth performance of broiler starter chickens fed varying levels of fibre and energy in multi-fibre sourcebased diets. Nigerian Journal of Animal Science 19 (2), $83-93$.

Salami, R .I. \& Odunsi, A. A. (2017e) Crude fibre versus Roxazyme ${ }^{\mathbb{}} \mathrm{G}^{2} \mathrm{G}$ inclusion levels in sub optimum energy diets for broiler chickens: effect on blood profile. Inter J Agri Biosci 6 (6), $311-315$. www.ijagbio.com.
Salami, R. I. \& Odunsi, A. A. (2018a) Crude fibre versus Roxazyme ${ }^{\circledR} \mathrm{G}^{2} \mathrm{G}$ inclusion levels in sub optimum energy diets for broiler chickens: performance and carcass characteristics at 8 weeks of age. Intl J Agri Biosci 7 (1), 36 - 42. www. ijagbio.com.

Shang, H. M., Hu, T. M., Lu, Y. J. \& Wu, H. X. (2010) Effects of inulin on performance, egg quality, gut microflora and serum and yolk cholesterol in laying hens. Brit. Poult. Sci., 51 (6), $791-796$.

Sundu, B; Kumar, A. \& Dingle, J. (2006) Palm kernel meal in broiler diet: effect on chicken performance and health. Wld. Poult.Sci. Vol. 62 (2), $316-325$.

Tion, M. A., Orga, M. T. \& Adeka, I. A. (2005) The effects of calorie to protein ratio of practical dietson performance and carcass quality of broiler chickens. Nig. J. Anim. Prod 32 (2), 253 - 260.

Udedibe, A. B. I., Peter-Nwachukwu, F. I. \& Obikaonu, H. O. (2015) Use of qualitative feed restriction as a management strategy for finishing broilers. Nigerian Journal of Animal Production 42 (2), 151 - 157. 